\title{
Prevalence of helicobacter pylori infection in children with Vitamin B12 Deficiency - A cross- sectional observational study
}

\author{
Rajendra K Dhayal', Shree Krishan Vishnoi ${ }^{2}$, Rakesh Jora ${ }^{3}$, Sandeep Choudhary ${ }^{4}$ \\ ${ }^{1}$ Resident Doctor, ${ }^{2,4}$ Associate Professor, ${ }^{3}$ Senior Professor, Department of Pediatrics, Dr S N Medical College, \\ Jodhpur, Rajasthan, India
}

Background: Vitamin $\mathrm{B}_{12}$ deficiency is common in children but under diagnosed disorder. Helicobacter pylori infection plays an important role in the development of atrophic gastritis and related malabsorption. There may be a relationship between H.Pylori infection and vitamin B12 deficiency. Aims and Objective: To find out prevalence of Helicobacter pylori infection by endoscopic and histopathological findings, in children aged 2-18 years, with vitamin $B_{12}$ deficiency. Materials and Methods: Seventy-eight patients with deficient serum vitamin $B_{12}$ levels were evaluated. Upper GI Endoscopy was performed in all cases and gastric biopsies were obtained for histopathological examination and evidence of $\mathrm{H}$. pylori infection. Results: Tissue biopsy revealed chronic atrophic gastritis in 09 patients and chronic antral gastritis in 52 patients. H. pylori infection by histology was positive in 45(57.70\%) patients. We found significant correlation between atrophic gastritis and $\mathrm{H}$. pylori infection, as well as between $\mathrm{H}$. pylori infection and $\mathrm{B}_{12}$ deficiency. Conclusion: $\mathrm{H}$.pylori has an effect on gastric mucosa, which affects the absorption of vitamin $B_{12}$. Thus individuals with $B_{12}$ deficiency should be subjected for diagnostic evaluation of $\mathrm{H}$.pylori infection so that appropriate therapy can be initiated.

Key words: H.pylori; Vitamin $\mathrm{B}_{12}$ deficiency; Chronic gastritis; Malnutrition
Access this article online

Website:

http://nepjol.info/index.php/AJMS

DOI: 10.3126/ajms.v12i7.35351

E-ISSN: 2091-0576

P-ISSN: 2467-9100

Copyright (c) 2021 Asian Journal of Medical Sciences

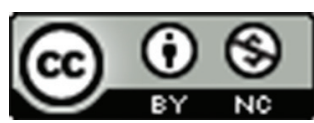

This work is licensed under a Creative Commons Attribution-NonCommercial 4.0 International License.

\section{INTRODUCTION}

Vitamin $B_{12}$ deficiency is common in children which produces megaloblastic anemia and neurological disorder. It is characterized by immature large erythrocytes in peripheral smear and cluster of neurological manifestations in children, which respond very rapidly to Vitamin $\mathrm{B}_{12}$ supplementation. ${ }^{1}$ Its prevalence is ranging from $7 \%$ to $50 \%$ in paediatricpopulation. ${ }^{2-4}$

Helicobacter pylori is one of the commonest bacterial pathogens in human. Prevalence of $\mathrm{H}$. pylori infection in India is $22 \%, 56 \%$ and $87 \%$ in $0-4,5-9$ and $10-19$ years age group respectively. ${ }^{5} \mathrm{H}$. pylori has been associated with suppression of the gastric acid barrier, allowing enteropathogens ingested from contaminated foods to gain access to the small intestine. This can cause childhood diarrhoea, malabsorption of essential micronutrients and growth failure in childhood. ${ }^{6,7}$

H. pylori infection is acquired early in life and grows up and once it is established, persists into adulthood. ${ }^{8}$ $\mathrm{H}$. pylori infection is the principal factor for malabsorption of vitamin $\mathrm{B}_{12}$ and play an important role in the development of megaloblastic anemia. ${ }^{9-11}$ Untreated $H$. pylori infection can lead to several complications like gastric ulcers, atrophic gastritis, duodenal ulcer, megaloblastic anemia, cardiovascular and cerebrovascular diseases. ${ }^{12}$ So early detection and eradication of Helicobacter pylori can prevent these complications.

We have planned this study to find out prevalence of Helicobacter pylori infection in children aged 2-18 years 
with vitamin $\mathrm{B}_{12}$ deficiency by doing upper GI endoscopy and histopathological examination of gastric mucosa.

\section{MATERIALS AND METHODS}

The Present cross sectional observational study was conducted over a period of one year at a tertiary care teaching hospital of Western India after approval of institute's ethical committee (ref no- SNMC/ IEC/2019/42, dated 09-03-2019). A total of 78 children, aged between 2 to 18 years with a serum vitamin $B_{12}$ level less than $200 \mathrm{pg} / \mathrm{dl}$ were included in the study.

\section{Inclusion criteria}

Children aged 2-18 years attending OPD/IPD with Vitamin $\mathrm{B}_{12}$ deficiency (Serum Vitamin $B_{12}$ level $\left.<200 \mathrm{pg} / \mathrm{ml}\right)^{13,14}$ and given the consent for endoscopy and histopathological study (gastric biopsy).

\section{Exclusion criteria}

- Diagnosed case of pernicious anemia or post gastrectomy.

- Evidence of renal failure or liver disease.

- Received prior H pylori eradication therapy or cyanocobalamin treatment parenterally.

Detailed history from parents of patients was recorded on a predesigned pro-forma.

Under all aseptic precautions blood samples were collected and transported within one hour to laboratory.

All enrolled patients were subjected to upper gastrointestinal endoscopy and two biopsy samples were taken from each antrum and corpus of stomach. The biopsy samples were preserved in formalin and sent to department of pathology, Dr. S.N. Medical College, Jodhpur for histopathological examination (Hematoxylin-Eosin and Giemsa stain) and two biopsy samples from each part use for Rapid Urease card test for $\mathrm{H}$. pylori. The density of helicobacter pylori i.e., chronic inflammatory infiltrate, inflammatory activity (polymorphonuclear cells), glandular atrophy and intestinal metaplasia were score $(0$; none, 1 ; mild, 2 ; moderate, or 3 : severe) according to the Sydney system. ${ }^{15}$

\section{Statistical analysis}

The statistical analysis was carried out using Statistical Package for Social Sciences (SPSS). All quantitative variables were estimated using measures of central location (mean, median) and measures of dispersion (standard deviation). For normally distributed data means were compared using student's t-test. Proportions were compared using Chi square or Fisher's exact test whichever was applicable. All statistical tests were performed at a significance level of $\mathrm{P}<0.05$.

\section{RESULTS}

In our study we enrolled 78 patients with proven Vitamin $\mathrm{B}_{12}$ deficiency. The mean age for male patients was $8.72 \pm$ 4.2 years, while in female patients it was $8.66 \pm 4.71$ years (M: $\mathrm{F}=1.17: 1) .52 .57 \%$ patients were from urban area, while $47.43 \%$ from rural area. Out of total 78 patients, $44.87 \%$ had serum Vitamin $B_{12}$ levels between $100-150 \mathrm{pg} / \mathrm{dl}$ while $19.23 \%$ cases had $<100 \mathrm{pg} / \mathrm{dl}$ and remaining $35.90 \%$ cases had $150-200 \mathrm{pg} / \mathrm{dl}$. Majority (46.67\%) of patients with vitamin $B_{12}$ level $<100 \mathrm{pg} / \mathrm{dl}$ were in age group $11-14$ years, while $45.71 \%$ patients with levels $100-150 \mathrm{pg} / \mathrm{dl}$ were in age group 6-10 years and $39.29 \%$ with levels $150-200 \mathrm{pg} / \mathrm{dl}$ were in age group 2-5 years.

On upper gastrointestinal endoscopic examination, we found gastric pallor as the commonest abnormality (75.64\%) followed by oesophageal mucosal pallor $(67.95 \%)$ and duodenal villous atrophy $(42.30 \%)$ while $21.79 \%$ patients had normal gastroesophageal endoscopic finding. All Patients with Vitamin $B_{12}$ levels $<100 \mathrm{pg} / \mathrm{dl}$ had gastric pallor while it is seen in $71.42 \%$ cases with vitamin $B_{12}$ level $100-150 \mathrm{pg} / \mathrm{dl}$.

In our study histopathological examination shown that $43.59 \%$ patients had mild chronic gastritis followed by moderate chronic antral gastritis in $14.10 \%$ and atrophic gastritis in $10.25 \%$ cases while normal gastric mucosa seen in $33.33 \%$ cases (Table 1).

Prevalence of H. Pylori in our study was $57.69 \%$ (Table 2). Cases of severe chronic antral gastritis have mean age 9.55 \pm 4.14 years, mean MCV $110.41 \pm 6.33 \mathrm{fl}(\mathrm{P}<0.0001)$, mean vitamin $B_{12}$ level $119.0 \pm 53.69 \mathrm{pg} / \mathrm{dl}$ and mean haemoglobin $4.97 \pm 2.20 \mathrm{gm} / \mathrm{L}$ and have $100 \% \mathrm{H}$. pylori positivity. We found significant correlation between severity of the chronic antral gastritis and mean corpuscular volume ( $\mathrm{p}$ value $<0.0001$ ) (Table 2). All cases with severe chronic antral gastritis depicted $\mathrm{H}$. pylori followed by moderate chronic antral gastritis $81.82 \%$ and their correlation found to be statistically significant $(\mathrm{P}<0.0001)$ i.e., more the

\begin{tabular}{|c|c|c|c|}
\hline \multirow[t]{2}{*}{ Biopsy finding } & \multicolumn{2}{|c|}{ Sex } & \multirow[t]{2}{*}{ Number (\%) } \\
\hline & Male & Female & \\
\hline $\begin{array}{l}\text { Mild Chronic } \\
\text { antral gastritis }\end{array}$ & 15 & 19 & $34(43.59 \%)$ \\
\hline $\begin{array}{l}\text { Moderate Chronic } \\
\text { antral gastritis }\end{array}$ & 7 & 4 & $11(14.10 \%)$ \\
\hline $\begin{array}{l}\text { Severe Chronic } \\
\text { antral gastritis }\end{array}$ & 4 & 3 & 07 (8.97\%) \\
\hline Atrophic gastritis & 4 & 5 & 09 (10.25\%) \\
\hline Normal & 16 & 10 & $26(33.33 \%)$ \\
\hline
\end{tabular}




\begin{tabular}{|c|c|c|c|c|c|c|}
\hline \multirow[t]{2}{*}{ Parameter (mean) } & \multicolumn{4}{|c|}{ HPE findings (Chronic antral gastritis) } & \multirow[t]{2}{*}{ Total } & \multirow[t]{2}{*}{$P$ value } \\
\hline & Mild & Moderate & Severe & Normal & & \\
\hline Age (years) & $7.49 \pm 4.86$ & $11.45 \pm 2.87$ & $9.55 \pm 4.14$ & $8.88 \pm 4.13$ & $8.70 \pm 4.46$ & 0.069 \\
\hline $\operatorname{MCV}(f l)$ & $88.72 \pm 16.44$ & $94.10 \pm 18.67$ & $110.41 \pm 6.33$ & $73.63 \pm 16.49$ & $86.37 \pm 19.22$ & $<0.0001$ \\
\hline Vitamin $B_{12}(p g / d l)$ & $128.73 \pm 41.90$ & $126.72 \pm 36.67$ & $119.0 \pm 53.69$ & $142.46 \pm 46.14$ & $132.15 \pm 43.63$ & 0.489 \\
\hline H. pylori $(+)$ & $26(76.47 \%)$ & $09(81.82 \%)$ & $07(100 \%)$ & $03(11.54 \%)$ & $45(57.69 \%)$ & $<0.0001$ \\
\hline H. pylori (-) & $08(23.53 \%)$ & $02(18.18 \%)$ & 00 & $23(88.46 \%)$ & $33(42.31 \%)$ & \\
\hline Hemoglobin (gm/L) & $5.87 \pm 2.25$ & $6.70 \pm 2.66$ & $4.97 \pm 2.20$ & $5.82 \pm 2.38$ & $5.89 \pm 2.34$ & 0.498 \\
\hline
\end{tabular}

abnormal changes in gastric biopsy findings more chances of detecting positive H. pylori infection (Table 2).

In our study, $45(57.70 \%)$ cases were positive for $\mathrm{H}$. pylori infection by Giemsa stain while 38(48.71\%) cases were positive by Rapid urease test (Table 3).

When we compared the H. Pylori positivity with Giemsa and Rapid urease test, we found all cases with severely density were also positive with Rapid urease test ( $P$ value- $<0.0001)$ while positivity with moderate and mild density was $94.73 \%$ and $70 \%$ respectively (Table 4 ).

In patients with severe density of $\mathrm{H}$. pylori $(83.33 \%)$ there is more macrocytosis in PBF, and their correlation was found to be statistically significant (P value <0.05) (Table 5).

$65.71 \%$ cases were with vitamin $\mathrm{B}_{12}$ levels between $100-150 \mathrm{pg} / \mathrm{dl}$ had H. pylori followed by $53.33 \%$ cases with levels $<100 \mathrm{pg} / \mathrm{dl}$ and $50 \%$ cases with levels 150-200 pg/dl.(P-0.423) (Table 6).

\section{DISCUSSION}

In our study we have found prevalence of H. Pylori was $57.69 \%$ in vitamin B12 deficiency children, similarly Kaptan et $\mathrm{al}^{11}$ showed presence of $\mathrm{H}$. pylori in $56 \%$ of the 138 patients with Vitamin B12 deficiency, and eradication treatment for $\mathrm{H}$. pylori resulted in improvement of Vitamin B12 level. In our study majority of cases with vitamin $\mathrm{B}_{12}$ level $<100 \mathrm{pg} / \mathrm{dl}$ were in age group 11-14 years. In a similar study Ramani et $\mathrm{al}^{16}$ found megaloblastic anemia was more common in the age group of 11-15 years. Shuval-Sudai et $\mathrm{al}^{17}$ found significant association of H.pylori infection and low prevalence of cobalamin and folate levels. Ravi K et $\mathrm{al}^{18}$ found significant association between the $\mathrm{H}$. pylori status and serum B12 level, in their study more than $60 \%$ of $\mathrm{H}$. pylori negative cases had serum $\mathrm{B}_{12}$ value greater than 100 , whereas among those patients with positive $H$. pylori status, majority ( $58 \%$ ) had vitamin $\mathrm{B}_{12}$ value less than 100 , while we have not found any statistically significant correlation between level of vitamin $\mathrm{B}_{12}$ deficiency and H. pylori infection as a cause, which may be due to small

\begin{tabular}{|c|c|c|c|c|}
\hline \multirow{2}{*}{$\begin{array}{l}\text { Helicobacter } \\
\text { pylori } \\
\text { (Giemsa } \\
\text { Stain) }\end{array}$} & \multicolumn{2}{|c|}{ Sex } & \multirow[t]{2}{*}{$P$ value } & \multirow[t]{2}{*}{ Number (\%) } \\
\hline & $\begin{array}{l}\text { Male } \\
(n=42)\end{array}$ & $\begin{array}{c}\text { Female } \\
(n=36)\end{array}$ & & \\
\hline Mild density & 09 & 11 & \multirow{4}{*}{$\begin{array}{c}x^{2}=0.975 \\
\text { d.f. }=3 ; \\
P=0.807\end{array}$} & $20(25.64 \%)$ \\
\hline $\begin{array}{l}\text { Moderate } \\
\text { density }\end{array}$ & 11 & 08 & & $19(24.36 \%)$ \\
\hline $\begin{array}{l}\text { Severe } \\
\text { density }\end{array}$ & 03 & 03 & & $06(7.69 \%)$ \\
\hline Negative & 19 & 14 & & $33(42.30 \%)$ \\
\hline $\begin{array}{l}\text { Helicobacter } \\
\text { Pylori } \\
\text { (Rapid } \\
\text { Urease Test) }\end{array}$ & $\begin{array}{c}\text { Male } \\
(n=42)\end{array}$ & $\begin{array}{c}\text { Female } \\
(n=36)\end{array}$ & & \\
\hline Positive & 19 & 19 & $x^{2}=0.190$ & 38 (48.71\%) \\
\hline Negative & 23 & 17 & $\begin{array}{c}\text { d.f. }=1 ; \\
P=0.662\end{array}$ & $40(51.28 \%)$ \\
\hline
\end{tabular}

\begin{tabular}{|c|c|c|c|c|}
\hline \multirow{2}{*}{$\begin{array}{l}\text { Helicobacter } \\
\text { pylori } \\
\text { (Giemsa } \\
\text { Stain) }\end{array}$} & \multicolumn{2}{|c|}{$\begin{array}{l}\text { Helicobacter Pylori } \\
\text { (Rapid Urease test) }\end{array}$} & \multirow[t]{2}{*}{$P$ value } & \multirow[t]{2}{*}{ Total } \\
\hline & Positive & Negative & & \\
\hline Mild density & $14(70 \%)$ & $06(40.0 \%)$ & $<0.0001$ & 20 \\
\hline $\begin{array}{l}\text { Moderate } \\
\text { density }\end{array}$ & $18(94.73 \%)$ & $01(2.50 \%)$ & & 19 \\
\hline $\begin{array}{l}\text { Severe } \\
\text { density }\end{array}$ & $06(100 \%)$ & $00(0.0 \%)$ & & 06 \\
\hline Negative & 00 & 33 (82.50\%) & & 33 \\
\hline Total & 38 & 40 & & 78 \\
\hline
\end{tabular}

sample size of our study, but we found high prevalence of $\mathrm{H}$. pylori infection in Vitamin $\mathrm{B}_{12}$ deficiency patients. Although Akcam Met al ${ }^{13}$ showed that H.pylori infection has a negative effect on serum vitamin $\mathrm{B}_{12}$ level. Our study shown Geimsa stain of gastric biopsy has more sensitivity to detect $H$. pylori infection as compare to rapid urease card test. We found significant association between chronic antral gastritis and $\mathrm{H}$. pylori infection, similar results also seen by Dholakia et $\mathrm{a}^{19}$ and Ravi et al in their study. Ravi $\mathrm{K}$ et $\mathrm{al}^{18}$ showed a high prevalence of chronic atrophic gastritis in patients with cobalamin deficiency (54.1\%) and $32.5 \%$ of them had evidence of chronic antral gastritis, 
Table 5: Comparison of peripheral blood film findings with Helicobacter pylori infection (Giemsa stain)

\begin{tabular}{|c|c|c|c|c|c|}
\hline \multirow[t]{2}{*}{ Hemogram (PBF) } & \multicolumn{4}{|c|}{ Helicobacter Pylori (Giemsa stain) } & \multirow[t]{2}{*}{ Total } \\
\hline & Mild & Moderate & Severe & Normal & \\
\hline Macrocytic cells & $06(30 \%)$ & $08(42.11 \%)$ & $05(83.33 \%)$ & 06 & 26 \\
\hline Microcytic cells & $04(25 \%)$ & $01(05.26 \%)$ & 00 & $14(42.42 \%)$ & 19 \\
\hline Normocytic cells & $03(15 \%)$ & $01(05.26 \%)$ & 00 & $04(12.12 \%)$ & 08 \\
\hline Microcytes with Macrocytes & $07(35 \%)$ & $06(31.58 \%)$ & $01(16.67 \%)$ & $06(18.18 \%)$ & 19 \\
\hline Normocytes with Macrocytes & 00 & $03(15.79 \%)$ & 00 & $03(09.09 \%)$ & 06 \\
\hline Total & 20 & 19 & 06 & 33 & 78 \\
\hline
\end{tabular}

Table 6: Correlation of Vitamin B12 levels with H. Pylori bacteria [ Giemsa stain]

\begin{tabular}{|c|c|c|c|c|c|}
\hline \multirow[t]{2}{*}{ H. Pylori status } & \multicolumn{3}{|c|}{ Vitamin $B_{12}$ level (pg/dl) } & \multirow[t]{2}{*}{ Total } & \multirow[t]{2}{*}{$P$ value } \\
\hline & Less than 100 & $100-150$ & $150-200$ & & \\
\hline Present & 08 (53.33\%) & $23(65.71 \%)$ & $14(50 \%)$ & 45 & $x^{2}=1.71$ \\
\hline Absent & 07 (46.67\%) & $12(34.29 \%)$ & $14(50 \%)$ & 33 & d.f.=2; \\
\hline Total & 15 & 35 & 28 & 78 & $P=0.423$ \\
\hline
\end{tabular}

majority $(56.6 \%)$ of them also showed evidence of H. pylori infection on biopsy.

\section{CONCLUSION}

In our study we have found prevalence of having $\mathrm{H}$. pylori infection in children with vitamin $\mathrm{B}_{12}$ deficiency was $57.70 \%$. In paediatric patients with vitamin $\mathrm{B}_{12}$ deficiency usually manifest in older age group but whenever we come across the cases with vitamin $\mathrm{B}_{12}$ deficiency, apart from nutritional cause we should also keep $\mathrm{H}$. pylori infection as one of cause of vitamin $B_{12}$ deficiency. Although we found significant correlation between severity of the chronic antral gastritis with H. pylori infection, yet we have not found any statistically significant correlation between $H$. pylori infection and level of vitamin $B_{12}$ deficiency, which may be due to small sample size of our study.

We recommend that further studies should be done with large sample size to find out $\mathrm{H}$. pylori infection as a definitive cause of vitamin $\mathrm{B}_{12}$ deficiency.

\section{REFERENCES}

1. García-Casal MN, Osorio C, Landaeta M, Leets I, Matus P, Fazzino $F$, et al. High prevalence of folic acid and vitamin B12 deficiencies in infants, children, adolescents and pregnant women in Venezuela. Eur J Clin Nutr. 2005;59(9):1064-1070. https://doi.org/10.1038/sj.ejcn.1602212

2. Bhende YM. Some experience with nutritional megaloblastic anemia. J Postgrad Medicine. 1965; 11:145-55.

3. Mittal VS and Agarwal KN. Observations on nutritional megaloblastic anemia in early childhood. Ind J Med Research. 1969; 57:730-738.

4. Gomber S, Kela K and Dhingra N. Clinico-hematological profile of megaloblastic anemia. Indian Pediatr. 1998; 35:54-57.
5. Chan FKL and Leung WK. Peptic ulcer disease. Lancet. 2002; 360: 933-941. https://doi.org/10.1016/S0140-6736(02)11030-0

6. Yakoob J, Jafri W and Abid S. Helicobacter pylori infection and micronutrient deficiencies. World J Gastroenterol. 2003; 9: 2137-2139.

https://doi.org/10.3748/wjg.v9.i10.2137

7. Cardenas VM, Mulla ZD, Ortiz M and Graham DY. Iron deficiency and Helicobacter pylori infection in the United States. Am J Epidemiol. 2006;163: 127-134.

https://doi.org/10.1093/aje/kwj018

8. Mishra S, Singh V, Rao GR, Dixit VK, Gulati AK and Nath G. Prevalence of Helicobacter pylori in asymptomatic subjects-a nested PCR based study. Infect Genet Evol. 2008; 8: 815-819. https://doi.org/10.1016/j.meegid.2008.08.001

9. Cohen $\mathrm{H}$, Weinstein WM and Carmel R. Heterogeneity of gastric histology and function in food cobalamin malabsorption: absence of atrophic gastritis and achlorhydria in some patients with severe malabsorption. Gut. 2000; 47:638-645. https://doi.org/10.1136/gut.47.5.638

10. Kaptan K, Beyan C, Ural AU, Çetin T, Avcu F and Gülșen M. Helicobacter pylori-is it a novel causative agent in vitamin B12 deficiency? Arch Intern Med. 2000;160(9):1349-1353.

https://doi.org/10.1001/archinte.160.9.1349

11. Stopeck A. Links between Helicobacter pylori infection, cobalamin deficiency, and pernicious anemia. Arch Intern Med. 2000; 160:1229-1230.

https://doi.org/10.1001/archinte.160.9.1229

12. Del Corral A and Carmel R. Transfer of cobalamin from the cobalamin-binding protein of egg yolk to $R$ binder of human saliva and gastric juice. Gastroenterology. 1990; 98: 1460-1466. https://doi.org/10.1016/0016-5085(90)91076-I

13. Akcam M, Artan R, Gelen T, Yilmaz A, Eren E, Uygun V, et al. Long-term aspects of nodular gastritis in children. Pediatr Int. 2007; 49: 220-225.

https://doi.org/10.1111/j.1442-200X.2007.02329.x

14. Andrès $\mathrm{E}$, Loukili NH, Noel E, Kaltenbach G, Abdelgheni MB, Perrin $A E$, et al. Vitamin $B_{12}$ (cobalamin) deficiency in elderly patients. CMAJ. 2004; 171:251-259.

https://doi.org/10.1503/cmaj.1031155 
15. Dixon MF, Genta RM, Yardley JH and Correa P. Classification and grading of gastritis. The updated Sydney System. International Workshop on the Histopathology of Gastritis, Houston 1994. Am J Surg Pathol. 1996;20(10):1161-1181.

https://doi.org/10.1097/00000478-199610000-00001

16. Ramani M, Ranganath D, RadhikaKrishna H, K.Geetha, Keerthika M, Deshmukh P, et al. Clinico Pathological Review Of Megaloblastic Anaemia In Children- A 7 Year Paediatric Hospital Experience. Journal of Evolution of Medical and Dental sciences. 2013;23(2):4136-4142.

https://doi.org/10.14260/jemds/812

17. Shoval SO and Granot E. Helicobacter pylori-an association with low serum vitamin $B_{12}$ levels. Gastroenterology. 2001; 12:0(5). https://doi.org/10.1016/S0016-5085(08)83668-2

18. Ravi K, Jacob J and David MT. Helicobacter pylori infection and vitaminB-12 deficiency-A cross sectional study. Asian Journal of Medical Sciences. 2017;8(4):16-20.

https://doi.org/10.3126/ajms.v8i4.17280

19. Dholakia KR, Dharmarajan TS, Yadav D, Oiseth S, Norkus EP and Pitchumoni CS. Vitamin B12 deficiency and gastric histopathology in older patients. World J Gastroenterol. 2005; 11:45, 7078-7083.

https://doi.org/10.3748/wjg.v11.i45.7078

\section{Author's Contribution:}

RJ-Concept and design of the study; prepared first draft of manuscript; RD- Interpreted the results; reviewed the literature and manuscript preparation;

SV- Concept, coordination, review of literature and manuscript preparation; SC- Statistically analysed and interpreted, preparation of manuscript and revision of the manuscript.

Work Attributed to:

Umaid Hospital, Dr S N Medical College, Jodhpur, Rajasthan, India

\section{ORCID ID:}

Dr Rajendra K Dhayal- (1) https://orcid.org/0000-0003-0664-6980

Dr Shree K Vishnoi- (1) https://orcid.org/0000-0003-1901-8828

Dr Rakesh Jora- (D) https://orcid.org/0000-0001-8875-9617

Dr Sandeep Choudhary- (i) https://orcid.org/0000-0002-6172-6097

Source of Funding: None, Conflicts of Interest: None. 